\title{
Pengaruh Pola Komunikasi Dan Kecerdasan Emosional Orang Tua Terhadap Akhlak Remaja
}

\author{
Sahriani Hasibuan, ${ }^{1}$ Muhammad Darwis Dasopang ${ }^{2}$ \\ STIKES Syuhada Padangsidimpuan1, Institut Agama Islam Negeri Padangsidimpuan² \\ Email: Sahrianihasibuan34889@gmail.com¹, mhddasopang@iain-padangsidimpuan.ac.id²
}

\section{Abstrak}

Tujuan penelitian ini adalah untuk menguji teori yang kemudian dianalisis kembali menjadi sebuah temuan baru. Jenis penelitian ini yaitu kuantitatif dengan metode kolerasional yang diperoleh dari angket. Hasil penelitian ini menunjukkan bahwa pola komunikasi orang tua $\left(\mathrm{X}_{1}\right)$ terhadap akhlak remaja $(\mathrm{Y})$ memiliki korelasi 0,890 atau $89 \%$ menunjukkan hubungan yang sangat kuat. Korelasi kecerdasan emosional orang tua $\left(\mathrm{X}_{2}\right)$ dengan akhlak remaja $(\mathrm{Y})$ memiliki nilai 0,926 atau 92\% menunjukkan hubungan yang sangat Kuat. Sedangkan untuk menguji tingkat signifikanuji $F 5 \%$, pengaruh pola komunikasi orang tua terhadap ahklak remaja, menunjukkan bahwa $F_{h}(270,761)>F_{t}(0,000)$ menunjukkan hubungan yang sesuai dan dapat diterima.

Kata Kunci: Pola komunikasi; kecerdasan emosional; akhlak.

\section{Abstract}

The purpose of this study is to test the theory which is then analyzed again into a new finding. This type of research is quantitative with a collaborative method obtained from a questionnaire. The results of this study indicate that the pattern of parental communication (X1) towards adolescent morals $(\mathrm{Y})$ has a correlation of 0.890 or $89 \%$ showing a very strong relationship. The correlation of emotional intelligence of parents (X2) with the morals of adolescents $(\mathrm{Y})$ has a value of 0.926 or $92 \%$ indicating a very strong relationship. Whereas to test the significance level of $F 5 \%$, the effect of parental communication patterns on adolescent behavior shows that Fh $(270,761)>\mathrm{Ft}(0,000)$ shows an appropriate and acceptable relationship.

Keywords: Communication patterns; emotional intelligence; morals. 


\section{Pendahuluan}

Lingkungan keluarga adalah ranah utama dan yang paling awal dalam membentuk pribadi, karakter dan moralitas remaja.Yang di dalamnya terdapat orang tua sebagai sosok yang paling dekat dalam kehidupan remaja. Cara berkomunikasi orang tua dan kemampuan orangtua dalam mengolah emosi bisa menentukan sikap, akhlak, prilaku dan pola pikir remaja. Oleh orang tua terhadap anak remaja. Yang mana sikap dan pribadi yang tampak berbeda dari orang tua dapat membentuk kepribadian anak remaja yang berbeda pula. ${ }^{1}$

Menurut Elizabeth Hurlock tindakan, sikap dan perilaku orang tua sehari-hari yang terlihat oleh remaja, sangat berdampak besar pada pembentukan karakter remaja. sikap dan perlakuan orang tua yang di bangun dengan awal yang baik dalam rumah, sangat berpengaruh terhadap pembentukan relasi dalam sebuah hubungan yang akan diterapkan dalam kehidupan keluarga dilingkungannya. ${ }^{2}$

Hurlock menyatakan yang dikutif dari pendapat Norman keikutsertaan dan pembinaan dari orang tua serta peran orang tua dalam memahami, mengenali sikap dan menggali potensi serta bakat yang unik dari remaja akan membentuk pribadi dan karakter yang natural tanpa memaksanya menjadi orang lain dan dan bahkan akan membentuk akhlak remaja yang baik tanpa rekayasa dan tidak akan menyimpang dari aturan dan norma yang seharusnya dimiliki pada usia remaja. ${ }^{3}$

Karakter remaja dapat dibentuk dengan komunikasi baik dari orang tua. Pola komunikasi orang tua terdiri atas beberapa jenis yaitu, demokratis, permissif,

1Ujang Saefullah, Kapita Seelekta Komunikasi Pendekatan Agama dan Budaya (Bandung:Simbiosa Rekatama Media,2007), hIm. 2.

2 Elizabeth B H, Perkembangan Anak (terjemahan) (Erlangga: Jakarta, 1993), hlm .130.

${ }^{3}$ Elizabeth Hurlock, Perkembangan Anak..., hlm. 132. 
otoriter dan melantarkan. Setiap pola komunikasi ini dapat memberikan pengaruh serta dampak baik dan buruk terhadap perkembangan usia remaja. ${ }^{4}$

Orang tua bertanggung jawab besar terhadap pendidikan anak remaja tentang perkara ini Allah swt berfirman dalam Qur'an surah At-Tahrim ayat 6:

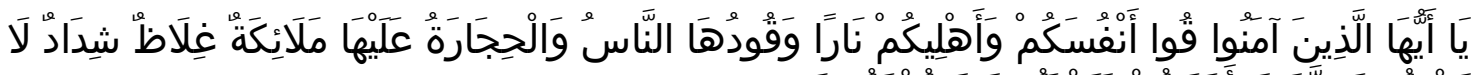

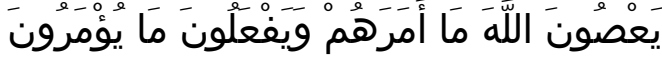

Artinya: "Hai orang-orang yang beriman periharalah dirimu dan keluargamu dari api neraka yang bahan bakarnya adalah manusia dan batu.: penjaganya malaikatmalaikat yang kasar, keras dan tidak mendurhakai Allah terhadap apa yang diperintahkan-Nya kepada mereka dan selalu mengerjakan apa yang diperintahkan" (At-Tahrim:6). ${ }^{5}$

Dalam setiap periode peralihan, status individu tidaklah jelas dan terdapat keraguan akan peran-peran yang harus dilakukan. Pada masa ini, remaja bukan lagi seorang anak-anak dan juga bukan seorang dewasa mailkan berada di masa peralihan yaitu masa yang sangat membutuhkan dukungan dan peran orang tua secara penuh dalam menyesuaikan diri di lingkugan sosialnya. ${ }^{6}$

Salah satu tugas perkembangan remaja yang tersulit adalah yang berhubungan dengan penyesuaian sosial. Remaja harus menyesuaiakn diri dengan keadaan sekitar sekolah terutama lawan jenisnya. Demi tercapainya tujuan dari pola sosialisasi ini, remaja harus banyak penyesuaian baru dengan lingkungan sekitarnya. ${ }^{7}$

4 Eva Latipah, Pengantar Psikologi Pendidikan (Yogyakarta: Pedagogia, 2012), hlm. 240241.

5 Departemen Agama Republik Indonesia, Al-Quran dan Terjemah (Bandung: Diponegoro, 2005), hlm. 448.

'Elizabeth B H,Perkembangan Anak (terjemahan) (Erlangga: Jakarta, 1993), hlm 209.

${ }^{7}$ Akrim Ridho Mursi, Jadi Remaja Penuh Warna (terjemahan) (Surakarta:Ziyad 2007), hlm. 221. 
Dalam penelitian ini di dukung oleh dua teori yang ingin di uji signifikannya yang berkaitan dengan akhlak remaja. Akhlak merupakan semua yang dibiasakan oleh orangtua yang diteladani oleh remaja. Baik sifat, cara memimpin, gaya bicara, dan seluruh prilaku dan perasaan yang ditunjukkan leh orang tua kepada remaja dalam kehidupan sehari-hari. ${ }^{8}$ Pada teori pembentukkan akhlak salah satunya disebut dengan teori kohlbetg.

Dalam teori Kohlberg sebagaimana dikutip oleh Jhon W Santrok, remaja memiliki tiga tingkatan moral yang masing-masing diantaranya memiliki dua tahap. Tingkatan pertama adalah pra konvensional, dimana didalamnya individu belum memperlihatkan adanya internalisasi dari nilai-nilai moral penalaran moral dikontrol oleh hadiah dan hukuman eksternal. Tingkatan kedua merupakan tingkat konvensional, individu didalamnya mulai mengikuti standar-standar tertentu, namun standar itu ditetapkan oleh orang lain, misalnya yang didtentukan oleh orang tua atau pemerintah. Tingkatan terakhir adalah pasca konvensional, pada tingkatan ini moralitas sepenuhnya diinternalisasi dan tidak didasarkan pada standar-standar orang lain. ${ }^{9}$

Selanjutnya aliran empirisme, ini dipelopori oleh john lock, dengan teori "tabul rasae" (meja lilin), yang menyebutkan bahwa manusia lahir dengan jiwa yang kosong dari kemampuan (potensi) dasar yang di umpamakan seperti meja lilin yang putih bersih. Menurut aliran ini faktor yang paling mempengaruhi terhadap pembentukkan akhlak seseorang adalah faktor dari luar diri seseorang, yaitu lingkungan sosial, serta pembinaan dan pendidikan yang diberikan oleh orang tua kepada remaja. Jika orang tua memberikan pembinaan dan pendidikan yang baik terhadap anak remaja maka baiklah anaknya. Demikian jika sebaliknya aliran ini

8Rosihon Anwar, Akhlak Tasawuf, (Bandung, PustakaSetia, 2010),hlm.11.

9Jhon W. Santrock, Remaja (Jakarta : Erlangga, 2007) , hlm .304-305. 
begitu percaya kepada peranan yang dilakukan oleh dunia dan pengajaran. Teori ini berpendapat bahwa pengaruh dalam diri (internal) tidak berdaya sama sekali. 10

Dari beberapa uraian di atas bahwa Pola komunikasi antara orang tua dan anak adalah bentuk hubungan orang tua dan anak dalam menjalin kedekatan sehingga memberikan rasa aman bagi anak, yang menjadikan proses komunikasi keduanya saling terbuka. ${ }^{11}$

Dan kecerdasan emosional antara orang tua dan anak adalah orang tua harus memberikan rasa nyama terhadap anak remaja, ketika anak berada di dalam rumah dan orang tua juga harus menyesuaikan kondisi emosi anak remaja agar tidak salah dalam memberikan tindakan, dan orang tua yang cerdas itu bisa mengolah emosi dan memotivasi, dan control orang tua yang baik sehingga akhlak dan budi pekerti yang baik akan tercipta sendiri pada diri anak remaja. ${ }^{12}$

Studi awal yang penulis lakukan di Desa Aek Badak Kecamatan Sayurmatinggi Kabupaten Tapanuli Selatan, problematika yang ada dalam lingkungan keluarga sangat mengancam terhadap terbentuknya prilaku atau akhlak terpuji remaja. Meskipun orang tua telah menunjukkan pola komunikasi dan kecerdasan emosional yang baik namun akhlak dan prilaku terpuji anak remaja di Desa Aek Badak Kecamatan Sayurmatinggi Kabupaten Tapanuli Selatan belum tercerminkan dalam kehidupan mereka sehari-hari.

Seperti orang tua yang memiliki pola komunikasi terbuka pada anaknya yaitu selalu menceritakan apa masalah dalam keluarga dan selalu mencari tau apa permasalahan anaknya, namun anak remajanya masih berprilaku tertutup kepada

10Abudin Nata, Akhlak Tasawuf (cetakan ke-9)(Jakarta: Pt Gravin dopersada, 2010), hlm. 167.

${ }^{11}$ H.A.W. Widjaja, Komunikasi: Komunikasi dan Hubungan Masyarakat (Jakarta:Bumi Aksara,2002), hlm. 8-9.

12Daniel Golman, Emotional Intelligence (terjemahan) (Jakarta: PT Gramedia Pustaka Utama, 2002), hlm. 411. 
orang tuanya dan bahkan karena sikap orang tuanya itu yang terbuka membuat anak rishi dan mencari sesuatu yang membuat remaja nyaman di luar rumah. Selain itu juga, Kecerdasan emosional orang tua dalam membentuk akhlak remaja untuk bertingkah laku yang sesuia dengan tingkat usia remaja.

Seperti orang tua yang terlalu egois dan mementingkan diri sendiri tampa mempedulikan apapun yang diinginkan anaknya, sehingga anak remaja salah paham dalam setiap segi kehidupannya yang memicu pada penyimpangan. dan juga ada remaja yang orang tuanya selalu bersikap simpati pada anak remaja membuat anak remaja bersikap melunjak dan semena-mena pada orang tuanya. Semestinya jika pola komunikasi orang tua sudah baik dan kecerdasan emosional orang tua juga baik dan setara dengan jenjang usia anak maka prilaku atau akhlak yang ditunjukkan anak remajapun akan berakhlak terpuji. Namun pada kenyataannya tidak seperti yang ada di dalam teori tersebut. Untuk mengatasi hal tersebut orang tua memikirkan berbagai pola komunikasi dan kecerdasan emosional orang tua terhadap akhlak remaja yang baik untuk dan tepat sasaran, melalui pengawasan atau kontrol, pola komunikasi dan kecerdasan emosional orang tua terhadap akhlak remaja yang terpuji.

Berdasarkan temuan awal diatas, penulis akan meneliti "Pengaruh Pola Komunikasi dan Kecerdasan Emosional Orang tua Terhadap Akhlak Remaja di Desa Aek Badak Kecamatan Sayurmatinggi Kabupaten Tapanuli Selatan”.

\section{Metode penelitian}

Berdasarkan masalah, penelitian ini termasuk penelitian kolerasional dengan menggunakan desain kausal komparatif. ${ }^{13}$ Artinya penelitian ini dilakukan untuk mengetahui hubungan fungsional kausalitas dan perbandingan besarnya pengaruh masing-masing variabel.

13lbnu Hadjar, Dasar-Dasar Metodologi Penelitian Kuantitatif dalam Pendidikan (Jakarta: Raja Grafindo Persada, 1999), hlm. 344. 
Berdasarkan tujuan, penelitian ini termasuk penelitian verifikatif yaitu penelitian yang bertujuan untuk menguji teori. Sedangkan berdasarkan tempat, penelitian ini termasuk penelitian lapangan. Berdasarkan pendekatan analisis data, penelitian ini menggunakan pendekatan kuantitatif yaitu penelitian yang dilakukan dengan pengukuran angka dan dianalisis dengan menggunakan statistik. ${ }^{14}$

Berdasarkan metode, penelitia ini menggunakan metode Ex Post Facto dimaksudkan untuk menguji apa yang telah terjadi pada subjek. Disebut Ex Post Facto secara harfiyah berarti "sesudah fakta", karena kausa atau sebab yang akan diselidiki tersebut sudah berpengaruh pada variabel lain. ${ }^{15}$

Pada penelitian ini peneliti menggunakan metode Slovin untuk penentuan jumlah sampel. Dari penghitungan diperoleh sampel sebanyak 73 orang remaja yang terdiri 32 remaja laki-laki dan 41 remaja perempuan yang berusia 13-16 tahun. Setelah jumlah sampel didapat, maka dilakukan penghitungan sampel dengan teknik random sampling yaitu pemilihan sampel secara acak. ${ }^{16}$

Adapun instrumen penelitian yang digunakan dalam penelitian ini yaitu Angket (kuesioner) adalah sejumlah pertanyaan tertulis yang digunakan untuk memperoleh informasi dari responden dalam arti laporan tentang pribadinya atau hal-hal yang ia ketahui dengan jumlah soal sebanyak 120 soal. Intrumen yang digunakan dalam penelitian ini adalah angket bentuk alternatif jawaban Skala Likert untuk mendapatkan seluruh data variabel bebas yaitu pola komunukasi orangtua dan kecerdasan emosional orangtau serta variabel terikat akhlak remaja. Jenis angket yang digunakan ialah angket tertutup. Angket tertutup adalah angket (kuesioner)

${ }^{14}$ Suharsimi Arikunto, Prosedur Penelitian Suatu Praktek (Jakarta: PT. Rineka Cipta. 2002), hlm. 10.

15lbnu Hadjar, Dasar-Dasar..., hlm. 344.

${ }^{16}$ Ahmad Nizar Rangkuti, MetodePenelitianPendidikan: PendekatanKuantitatif, Kualitatif, PTK, danPenelitianPengembangan (Bandung: Citapustaka Media, Edisi Revisi, 2016), hlm. 48. 
yang sudah disediakan jawabannya sehingga responden tinggal memilih. ${ }^{17}$ untuk mengetahui keterandalan dan keabsahan angket yang akan digunakan. Di uji dengan Langkah-langkah pembuatan angket yang baik yaitu dengan uji validitas dan uji reliabilitas angket.

Dalam menganalisis data peneliti menggunakan pendekatan analisa kuantitatif. Pada statistik akan dikemukakan cara-cara penyajian data atau analisis data untuk menguji teori pada penelitian ini, maka digunakan rumus korelasi ganda dan regresi berganda, dan juga Perhitungan ditentukan dengan menggunakan bantuan program SPSS 22 (Statistical Product and Service Solution) 16 for Windows.

\section{Hasil dan Pembahasan Penelitian}

\section{Hasil Pengujian Hipotesis}

a. Hipotesis pertama berbunyi "Terdapat pengaruh yang signifikan antara pola komunikasi orangtua terhadap akhlak remaja di Desa Aek Badak kecamatan Sayurmatinggi kabupaten Tapanuli Selatan" sebagai jawaban terhadap rumusan masalah pertama dilakukan dengan rumus kolerasi pearson regresi sederhana dan uji signifikan yang di olah dengan bantuan program SPSS Versi 22.

Tabel 1

Rangkuman Hasil Statistik Kolerasi Pola Komunikasi Orang Tua

$\left(\mathrm{X}_{1}\right)$ dengan Akhlak Remaja $(\mathrm{Y})$

\begin{tabular}{|c|c|c|c|}
\hline & & $\begin{array}{c}\text { Pola Komunikasi } \\
\text { Orang } \\
\text { Tua }\end{array}$ & Akhlak Remaja \\
\hline Pola & Pearson Correlation & 1 &, $890^{* *}$ \\
\hline Komunikasi & Sig. (2-tailed) & & ,000 \\
\hline Orang Tua & $\mathrm{N}$ & 73 & 73 \\
\hline
\end{tabular}

${ }^{17}$ Suharsimi Arikunto, Prosedur Penelitian Suatu Praktek (Jakarta: PT. Rineka Cipta. 2002), hlm. 128-129. 


\begin{tabular}{|ll|r|r|} 
Akhlak & Pearson Correlation &, $890^{\star \star}$ & 1 \\
Remaja & Sig. (2-tailed) &, 000 & \\
& $\mathrm{~N}$ & 73 & 73 \\
\hline
\end{tabular}

**. Correlation is significant at the 0.01 level (2-tailed).

Pengujian hipotesis kedua dilanjutkan dengan analisis regresi.

Tabel 2

Rangkuman Hasil Statistik Pengaruh Pola Komunikasi Orang Tua $\left(\mathrm{X}_{1}\right)$ terhadap Akhlak Remaja(Y)

\begin{tabular}{|l|r|r|r|r|r|}
\hline & \multicolumn{2}{|c|}{$\begin{array}{c}\text { Unstandardized } \\
\text { Coefficients }\end{array}$} & $\begin{array}{c}\text { Standardized } \\
\text { Coefficients }\end{array}$ & \\
\cline { 2 - 4 } & \multicolumn{1}{|c|}{ B } & Std. Error & Beta & T & Sig. \\
\hline $\begin{array}{l}\text { Model } \\
\text { Pola Komstant) } \\
\text { Orang Tua }\end{array}$ & 5,586 & 6,009 & &, 930 &, 356 \\
\hline
\end{tabular}

a. Dependent Variable: Akhlak Remaja

Selanjutnya dilakukan Uji-F signifikasi pengaruh pola komunikasi orang tua terhadap akhlak remaja, dapat dilihat pada tabel di bawah ini:

\section{Tabel 3}

Hasil Uji-F Signifikasi Variabel Pengaruh Pola Komunikasi Orang Tua( $\left.\mathrm{X}_{1}\right)$ terhadap Akhlak Remaja(Y)

\begin{tabular}{|l|c|c|c|c|c|}
\hline Model & $\begin{array}{c}\text { Sum of } \\
\text { Squares }\end{array}$ & Df & Mean Square & F & Sig. \\
\hline
\end{tabular}




\begin{tabular}{|r|r|r|r|r|r|}
\hline 1 & 4596,130 & 1 & 4596,130 & 270,761 &, $000^{\mathrm{b}}$ \\
Regression & 1205,213 & 71 & 16,975 & & \\
Residual & & & & \\
\hline Total & 5801,342 & 72 & & & \\
\hline
\end{tabular}

a. Dependent Variable: Akhlak Remaja

b. Predictors: (Constant), Pola Komunikasi Orang Tua

Hipotesis kedua berbunyi "Terdapat pengaruh kecerdasan emosional orangtua terhadap akhlak remaja di Desa Aek Badak Kecamatan Sayurmatinggi Kabupaten Tapanuli Selatan. "sebagai jawaban terhadap rumusan masalah pertama dilakukan dengan rumus kolerasi pearson regresi sederhana dan uji signifikan uang di olah dengan bantuan program SPSS Versi 22.

Tabel 4

Rangkuman Hasil Statistik Kolerasi Kecerdasan Emosional Orang Tua( $\left.\mathrm{X}_{2}\right)$ dengan Akhlak Remaja (Y)

\begin{tabular}{|c|c|c|c|}
\hline & & $\begin{array}{c}\text { Kecerdasan } \\
\text { Emosional Orang } \\
\text { Tua }\end{array}$ & Akhlak Remaja \\
\hline $\begin{array}{l}\text { Kecerdasan } \\
\text { Emosional } \\
\text { Orang Tua }\end{array}$ & $\begin{array}{l}\text { Pearson } \\
\text { Correlation } \\
\text { Sig. (2-tailed) } \\
\text { N }\end{array}$ & $\begin{array}{r}1 \\
\\
73\end{array}$ & $\begin{array}{c}, 926^{* *} \\
, 000 \\
73\end{array}$ \\
\hline $\begin{array}{l}\text { Akhlak } \\
\text { Remaja }\end{array}$ & $\begin{array}{l}\text { Pearson } \\
\text { Correlation } \\
\text { Sig. (2-tailed) }\end{array}$ & $\begin{array}{l}, 926^{* *} \\
, 000\end{array}$ & 1 \\
\hline
\end{tabular}




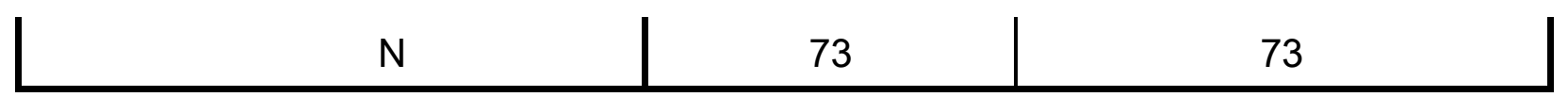

**. Correlation is significant at the 0.01 level (2-tailed).

Hipotesis kedua dilanjutkan dengan analisis regresi.

Tabel 5

Rangkuman Hasil Statistik Pengaruh Kecerdasan Emosional Orangtua $\left(\mathrm{X}_{2}\right)$ terhadap Akhlak Remja(Y)

\begin{tabular}{|c|c|c|c|c|c|}
\hline \multirow[b]{2}{*}{ Model } & \multicolumn{2}{|c|}{$\begin{array}{c}\text { Unstandardized } \\
\text { Coefficients }\end{array}$} & \multirow{2}{*}{$\begin{array}{c}\text { Standardized } \\
\text { Coefficients } \\
\text { Beta }\end{array}$} & \multirow[b]{2}{*}{$\mathrm{T}$} & \multirow[b]{2}{*}{ Sig. } \\
\hline & B & Std. Error & & & \\
\hline (Constant) & $\begin{array}{r}, 75 \\
4\end{array}$ & 5,000 & & 151 & 881 \\
\hline $\begin{array}{l}\text { Kecerdasan Emosional } \\
\text { Orang tua }\end{array}$ & $\begin{array}{r}, 93 \\
6\end{array}$ & ,045 & ,926 & 20,746 & ,000 \\
\hline
\end{tabular}

a. Dependent Variable: Akhlak Remaja

Selanjutnya dilakukan Uji-F signifikasi pengaruh kecerdasan emosional orang tua terhadap akhlak remaja, dapat dilihat pada tabel di bawah ini.

Tabel 6

Hasil Uji-F Signifikasi Variabel Pengaruh Kecerdasan Emosional Orang Tua $\left(\mathrm{X}_{2}\right)$ terhadap Akhlak Remaja $(\mathrm{Y})$

\begin{tabular}{|l|r|r|r|c|c|}
\hline Model & Sum of Squares & Df & Mean Square & $\mathrm{F}$ & \multicolumn{1}{c|}{ Sig. } \\
\hline $1 \quad$ Regression & 4979,831 & 1 & 4979,831 & 430,387 &, $000^{\mathrm{b}}$ \\
\multicolumn{1}{|c|}{ Residual } & 821,512 & 71 & 11,571 & & \\
\multicolumn{1}{|c|}{ Total } & 5801,342 & 72 & & & \\
\hline
\end{tabular}

a. Dependent Variable: Akhlak Remaja

b. Predictors: (Constant), Kecerdasan Emosional Orang Tua 
Pengujian hipotesis ketiga yang berbunyi "Terdapat pengaruh pola komunikasi dan kecerdasan emosional orangtua terhadap akhlak remaja di Desa Aek Badak Kecamatan Sayurmatinggi Kabupaten Tapanuli Selatan" sebagai jawaban atas rumusan masalah ketigadilakukan dengan menggunakan rumus kolerasi ganda, regresi ganda, regresi parsial dan uji signifikan dengan batuan pengolahan data SPSS.

Tabel 7

Rangkuman Hasil Statistik Kolerasi Ganda Pola Komunikasi $\left(\mathrm{X}_{1}\right)$ dan Kecerdasan Emosional Orangtua $\left(\mathrm{X}_{2}\right)$ dengan Akhlak Remaja $(\mathrm{Y})$

\begin{tabular}{|c|c|c|c|c|}
\hline & & $\begin{array}{c}\text { Pola } \\
\text { Komunikasi } \\
\text { Orang Tua }\end{array}$ & $\begin{array}{l}\text { Kecerdasan } \\
\text { Emosional } \\
\text { Orang Tua }\end{array}$ & Akhlak Remaja \\
\hline $\begin{array}{l}\text { Pola } \\
\text { Komunika } \\
\text { si } \\
\text { Orangtua }\end{array}$ & $\begin{array}{l}\text { Pearson } \\
\text { Correlation } \\
\text { Sig. (2-tailed) } \\
\mathrm{N}\end{array}$ & 73 & $\begin{array}{r}, 975^{* *} \\
, 000 \\
73\end{array}$ & $\begin{array}{r}, 890^{* *} \\
, 000 \\
73\end{array}$ \\
\hline $\begin{array}{l}\text { Kecerdas } \\
\text { an } \\
\text { Emosiona } \\
\text { I } \\
\text { Orangtua }\end{array}$ & $\begin{array}{l}\text { Pearson } \\
\text { Correlation } \\
\text { Sig. (2-tailed) } \\
\mathrm{N}\end{array}$ & $\begin{array}{r}, 975^{\star \star} \\
, 000 \\
73\end{array}$ & 1 & $\begin{array}{r}, 926^{* *} \\
73 \\
7300\end{array}$ \\
\hline $\begin{array}{l}\text { Akhlak } \\
\text { Remaja }\end{array}$ & $\begin{array}{l}\text { Pearson } \\
\text { Correlation } \\
\text { Sig. (2-tailed) } \\
\text { N }\end{array}$ & $\begin{array}{r}, 890^{* *} \\
, 000 \\
73\end{array}$ & $\begin{array}{r}, 926^{* *} \\
, 000 \\
73\end{array}$ & 73 \\
\hline
\end{tabular}

**. Correlation is significant at the 0.01 level (2-tailed). 
Selanjutnya dilakukan uji regresi ganda untuk mengetahui pengaruh variabel $\left(\mathrm{X}_{1}\right)$ dan $\left(\mathrm{X}_{2}\right)$ terhadap $(\mathrm{Y})$ berikut pada tabel di bawah ini:

Tabel 8

Rangkuman Hasil Statistik pengaruh Pola Komunikasi $\left(X_{1}\right)$ dan Kecerdasan Emosional Orang Tua $\left(\mathrm{X}_{2}\right)$ dengan Akhlak Remaja $(\mathrm{Y})$

\begin{tabular}{|c|c|c|c|c|c|}
\hline \multirow[b]{2}{*}{ Model } & \multicolumn{2}{|c|}{$\begin{array}{c}\text { Unstandardized } \\
\text { Coefficients }\end{array}$} & \multirow{2}{*}{$\begin{array}{c}\text { Standardized } \\
\text { Coefficients } \\
\text { Beta }\end{array}$} & \multirow[b]{2}{*}{$T$} & \multirow[b]{2}{*}{ Sig. } \\
\hline & B & $\begin{array}{l}\text { Std. } \\
\text { Error }\end{array}$ & & & \\
\hline $1 \quad$ (Constant) & 1,271 & 4,987 & & ,255 & ,799 \\
\hline $\begin{array}{c}\text { Pola Komunikasi } \\
\text { Orang Tua }\end{array}$ &,- 296 & 221 &,- 269 & $-1,344$ & 183 \\
\hline $\begin{array}{l}\text { Kecerdasan } \\
\text { Emosional } \\
\text { Orang Tua }\end{array}$ & 1,201 & ,202 & 1,188 & 5,945 & ,000 \\
\hline
\end{tabular}

a. Dependent Variable: Akhlak Remaja

Selanjutnya dilakukan Uji-F signifikasi pengaruh kecerdasan emosional orang tua terhadap akhlak remaja yaitu sebagai berikut.

\section{Tabel 9}

Hasil Uji-F Signifikasi Variabel Pengaruh Pola Komunikai $\left(X_{1}\right)$ Kecerdasan Emosional Orang Tua $\left(\mathrm{X}_{2}\right)$ terhadap Akhlak Remaja $(\mathrm{Y})$

\begin{tabular}{|l|l|l|l|l|l|}
\hline Model & Sum of Squares & Df & Square & F & Sig. \\
\hline
\end{tabular}




\begin{tabular}{|c|c|c|c|c|c|}
\hline $\begin{array}{l}1 \\
\text { Regression }\end{array}$ & 5000,490 & 2 & 2500,245 & 218,539 &, $000^{b}$ \\
\hline Residual & 800,852 & 70 & 11,441 & & \\
\hline Total & 5801,342 & 72 & & & \\
\hline
\end{tabular}

a. Dependent Variable: Akhlak Remaja

b. Predictors: (Constant), Kecerdasan Emosional Orang Tua, Pola Komunikasi Orang Tua

Tabel 10

Hasil Uji Determinan (R) Signifikasi Variabel Pengaruh Pola Komunikai $\left(X_{1}\right)$

Kecerdasan Emosional Orang Tua $\left(\mathrm{X}_{2}\right)$ terhadap Akhlak Remaja $(\mathrm{Y})$

\begin{tabular}{|c|c|c|c|c|c|c|c|c|c|}
\hline \multirow[b]{2}{*}{$\begin{array}{c}\text { Mod } \\
\text { el }\end{array}$} & \multirow[b]{2}{*}{$\mathrm{R}$} & \multirow[b]{2}{*}{$\begin{array}{c}\mathrm{R} \\
\text { Square }\end{array}$} & \multirow[b]{2}{*}{$\begin{array}{c}\text { Adjuste } \\
\text { d R } \\
\text { Square }\end{array}$} & \multirow{2}{*}{$\begin{array}{c}\text { Std. } \\
\text { Error of } \\
\text { the } \\
\text { Estimat } \\
\mathrm{e}\end{array}$} & \multicolumn{5}{|c|}{ Change Statistics } \\
\hline & & & & & $\begin{array}{c}\mathrm{R} \\
\text { Square } \\
\text { Chang } \\
\mathrm{e}\end{array}$ & $\begin{array}{c}\mathrm{F} \\
\text { Chang } \\
\mathrm{e}\end{array}$ & df1 & df2 & $\begin{array}{c}\text { Sig. F } \\
\text { Change }\end{array}$ \\
\hline 1 & $\begin{array}{c}, 928 \\
\text { a }\end{array}$ & ,862 & 858, & 3,382 & 862 & $\begin{array}{c}218,53 \\
9\end{array}$ & 2 & 70 & 000, \\
\hline
\end{tabular}

a. Predictors: (Constant), Kecerdasan Emosional Orang Tua, Pola

Komunikasi Orang Tua

\section{Hasil dan Pembahasan}

a. Pembahasan hasil hipotesis pertama variabel $X_{1}$ dengan $Y$

Hasil perhitungan menunjukkan bahwa signifikasi antara pola komunikasi orangtua $\left(\mathrm{X}_{1}\right)$ dengan akhlak remaja $(\mathrm{Y})$ adalah $0,000<0,05$ yang berarti terdapat kolerasi yang signifikan. Kolerasi yang terjadi bersifat positif, yaitu 0,890 atau 89 \%artinya bahwa interpretasi hubungan antara variabel $X_{1}$ dan $Y$ sangat Kuat, Hasil 
persaman regresi linier sederhana hipotesis satu menunjukkan bahwa persamaan regresinya dapat ditulis Garis persamaan regresiyaitu : $\ddot{y}=a+b X a$ adalah $\ddot{y}=5,586$ $+0,982 X$. Dari persamaan regresi di atas maka diambil interpretasi yaitu, sebelum pola komunikasi orangtua mempengaruhi akhlak remaja nilai akhlak remaja sudah sebesar 5.586 point. Jika pola komunikasi orangtua bertambah 1 point maka nilai akhlak remaja bertambah 0,982 point Selain menggambarkan persamaan regresi perhitungan juga memperoleh hasil uji signifikan terhadap uji t yaitu menunjukkan bahwa nilai thitung $=16,455>t_{\text {tabel}} 0.000$, maka ada pengeruh yang nyata (signifikan) variabel pola komunikasi orangtua terhadap akhlak remaja. Selanjutnya dilakukan Uji-F signifikasi pengaruh pola komunikasi orangtua terhadap akhlak remaja, menjelaskan bahwa $F_{\text {hitung }}=270,761(270,761)>F_{t}(0,000)$, , maka $\mathrm{H}_{0}$ ditolak dan $\mathrm{H}_{\mathrm{a}}$ diterima. Hal ini berarti bahwa hipotesis alternatif yang bebunyi "Terdapat pengaruh yang signifikan antara pola komunikasi orangtua terhadap akhlak remaja di Desa Aek Badak kecamatan Sayurmatinggi kabupaten Tapanuli Selatan" diterima.

b. Pembahasan hasil hipotesis kedua variabel $X_{2}$ dengan $Y$

Hasil perhitungan menunjukkan bahwa signifikasi antara kecerdasan emosional orangtua $\left(\mathrm{X}_{2}\right)$ dengan akhlak remaja $(\mathrm{Y})$ adalah $0,000<0,05$ yang berarti terdapat kolerasi yang signifikan. Kolerasi yang terjadi bersifat positif, yaitu $r_{h i t u n g}(0,926)$ artinya bahwa interpretasi hubungan antara variabel $\mathrm{X}_{2}$ dan $\mathrm{Y}$ sangat Kuat,. jika variabel kecerdasan emosional orangtua meningkat maka akan disertai oleh meningkatnya akhlak remaja Setelah diketahui bahwa kedua variabel tersebut memiliki hubungan yang sangat kuat.

Hasil persaman regresi linier sederhana hipotesis dua menunjukkan bahwa persamaan regresinya dapat ditulis: $\ddot{y}=a+b X a$ adalah $\ddot{y}=0,754+0,936 X$, Dari persamaan regresi di atas maka diambil interpretasi yaitu, sebelum kecerdasan emosional orangtua 0,936 point mempengaruhi akhlak remaja nilai akhlak remaja sudah sebesar0,754 point. Jika kecerdasan emosional orangtua bertambah 1 point maka nilai akhlak remaja bertambah 0,936 point. Selain menggambarkan persamaan 
regresi perhitungan juga menampilkan hasil uji signifikan terhadap uji $\mathrm{t}$ yaitu menunjukkan bahwa nilai $t_{\text {hitung }}=20,746>t_{\text {tabel }} 0.000$, maka ada pengeruh yang nyata (signifikan) variabel kecerdasan emosional orangtua terhadap akhlak remaja.

Selanjutnya dilakukan Uji-F signifikasi pengaruh kecerdasan emosional orangtua terhadap akhlak remaja, menjelaskan bahwa $F_{\text {hitung }}=430,387$. jika $F_{0}(43,487)>F_{t}$ $(0,000)$, Hal ini berarti bahwa hipotesis alternatif yang bebunyi "Terdapat pengaruh yang signifikan antara kecerdasan emosional orangtua terhadap akhlak remaja di Desa Aek Badak kecamatan Sayurmatinggi kabupaten Tapanuli Selatan" diterima.

c. Pembahasan hasil hipotesis ketiga variabel $X_{1}, X_{2}$ dengan $Y$

Hasil perhitungan variabel pola komunikasi dan kecerdasan emosional orangtua terhadap akhlak remaja tersebut menunjukkan bahwa nilai disignifikan untuk pola komunikasi orangtua terhadap akhlak remaja dengan thitung $-1,344<t_{\text {hitung }}-0.183$, maka dari itu variabel pola komunikasi orangtua ada pengaruh yang signifikan terhadap akhlak remaja. Selanjutnya untuk variabel kecerdasan emosional orangtua terhadap akhlak remaja dengan $t_{\text {hitung }} 5,945>t_{\text {hitung }} 0.000$, maka dari itu variabel kecerdasan emosional orangtua berpengaruh signifikan terhadap akhlak remaja. Artinya ada pengaruh secara bersamaan antara ketiga variabel.

Hasil pengujian hipotesis keseluruhan uji $\mathrm{F}$ hipotesis ketiga bahwa $\mathrm{F}_{\text {hitung }}=$ 218.539. jika $F_{0}(218,539)>F_{t}(0,000)$, maka $H_{0}$ ditolak dan $H_{a}$ diterima. Hal ini berarti bahwa hipotesis alternatif yang bebunyi "Terdapat pengaruh yang signifikan antara pola komunikasi dan kecerdasan emosional orangtua terhadap akhlak remaja di Desa Aek Badak kecamatan Sayurmatinggi kabupaten Tapanuli Selatan".

Besarnya hubungan antara pola komunikasi dan kecerdasan emosional orangtua terhadap akhlak remaja dalam pengujian pertama Dihitung dengan koefisien kolerasi adalah 0,928 atau $92 \%$ hal ini menunjukkan adannya hubungan yang sangat kuat.Sedangkan kontribusi atau sumbangan secara simultan variabel pola komunikasi dan kecerdasan emosional orangtua terhadap akhlak remaja adalah 0,862 atau $86,2 \%$ sedangkan sisanya ditentukan oleh variabel lain. 


\section{Kesimpulan}

Dari penelitian ini penulis menyimpulkan "Terdapat pengaruh pola komunikasi dan kecerdasan emosional orang tua terhadap akhlak remaja di Desa Aek Badak Kecamatan Sayurmatinggi Kabupaten Tapanuli Selatan”.

\section{Daftar Pustaka}

Abudin Nata, Akhlak Tasawuf (cetakan ke-9), Jakarta: Pt Gravin dopersada, 2010 Ahmad Nizar Rangkuti, MetodePenelitianPendidikan: PendekatanKuantitatif, Kualitatif, PTK, danPenelitianPengembangan, Bandung: Citapustaka Media, EdisiRevisi, 2016

Akrim Ridho Mursi, Jadi Remaja Penuh Warna (terjemahan), Surakarta : Ziyad, 2007.

Daniel Golman, Emotional Intelligence (terjemahan), Jakarta: PT Gramedia Pustaka Utama, 2002.

Departemen Agama Republik Indonesia, Al-Quran dan Terjemah, Bandung: Diponegoro, 2005.

Elizabeth B H, Perkembangan Anak (terjemahan), Erlangga: Jakarta, 1993.

Eva Latipah, Pengantar Psikologi Pendidikan, Yogyakarta: Pedagogia, 2012.

Hamzah Yaqub, Etika Islam Pembinaan Aklaqulkarimah, Bandung: Cv Diponegoro, 1983.

H.A.W. Widjaja, Komunikasi: Komunikasi dan Hubungan Masyarakat, Jakarta:Bumi Aksara,2002.

Ibnu Hadjar, Dasar-Dasar Metodologi Penelitian Kuantitatif dalam Pendidikan, Jakarta: Raja Grafindo Persada, 1999.

Imam Tirmidzi,Dar A/-Kotob A/-IImiyah, Beirut, Libanon. 1971.

Jhon W. Santrock, Remaja, Jakarta: Erlangga, 2007.

Rosihon Anwar, AkhlakTasawuf, Bandung, PustakaSetia, 2010 